\title{
MINERALOGICAL STUDIES ON BONE APATITE AND THEIR IMPLICATIONS FOR RADIOCARBON DATING
}

\author{
AFIFA A HASSAN*, JOHN D TERMINE**, \\ and C VANCE HAYNES, JR***
}

\begin{abstract}
Infrared (IR) spectrophotometry and X-ray diffraction (XRD) were conducted on modern and fossil bone material from archaeological sites in the $U S$ to determine post-mortem changes in bone apatite and to evaluate the effect of these changes on radiocarbon dating. IR absorption bands, XRD peak-broadening parameters, and XRD unit cell measurements indicated that during fossilization, bone apatite, a mineral similar to dahllite, was partially or completely recrystallized to francolite. Post-mortem changes involved then removal of some of the endogenous crystal carbonate both at surfaces and at internal $\mathrm{OH}$-sites and introduction of exogenous carbonate into internal crystal $\mathrm{PO}_{4}$ sites. Increased fluorine content accompanied carbonate substitution.

Both the carbon isotopic composition and the amount of exogenous carbonate introduced into the apatite structure will affect the radiocarbon dating of bone apatite. Special sample pre-treatment may remove most of the substituted carbonate in some cases. Simulated experiments are suggested for a better understanding of the nature and mechanism of carbonate substitution in bone apatite for the removal of the exogenously substituted carbon and the improvement of radiocarbon dates.
\end{abstract}

\section{INTRODUCTION}

Despite the abundance of bone material at archaeological sites, only a few radiocarbon dates have been obtained from them. Many workers regard bone dating with suspicion because of the inaccurate ages often obtained. The organic fraction in bone, namely collagen, does not exchange carbon with the bone post-mortem environment. Accordingly, inaccurate collagen dates are caused by physical contamination with other organic material, which has led many investigators to devise new techniques for separating pure collagen (Berger, Horney, and Libby, 1964; Krueger, 1965; Sellstedt and others, 1966; Berger and others, 1971; Longin, 1971; and Hassan, 1976). In many cases, however, the amount of collagen separated is insufficient for dating. Haynes (1968) used the bone mineral, apatite, as an alternative.

Many investigators are skeptical of radiocarbon dates obtained from bone apatite because of possible post-mortem exchange of carbon with the surrounding medium (Tamers \& Pearson, 1965; Sellstedt and others, 1966). One of us (CVH), in collaboration with Austin Long, University of Arizona (unpub), demonstrated this exchange by radiocarbon analysis of about 2 my old bone from the Curtis Ranch locality in Arizona and obtained apparent ages of 21,000 $\pm 1000 \mathrm{BP}(\mathrm{A}-1028)$ on apatite $\mathrm{CO}_{2}$ and $16,180 \pm 300$ BP (A-1027) on $\mathrm{CO}_{2}$ from secondary carbonate. The mechanism and magnitude of such exchange had not been studied before. In the present study, modern and fossil bone apatites were subjected to $\mathrm{X}$-ray and infrared investigation to trace the changes which might have 99164

* Department of Geology, Washington State University, Pullman, Washington

** Laboratory of Biological Structure, NIDR, National Institute of Health, Bethesda, Maryland 20014 85721

*** Department of Anthropology, The University of Arizona, Tucson, Arizona 


\section{TABLE 1}

Frequency for IR absorption bands (in $\mathrm{cm}^{-1}$ ) for the carbonate in dahllite, francolite, aragonite, calcite and bone apatite

\begin{tabular}{|c|c|c|c|c|}
\hline Samples & $\nu_{1}$ & $\nu_{2}$ & $\nu_{3}$ & $\nu_{4}$ \\
\hline $\begin{array}{l}\text { Dahllite } \\
\quad \text { (Carlström, in press) }\end{array}$ & & 873 & $\begin{array}{l}1416 \\
1455\end{array}$ & \\
\hline $\begin{array}{l}\text { Francolite } \\
\text { (Carlström, in press) }\end{array}$ & & 866 & $\begin{array}{l}1425 \\
1455\end{array}$ & \\
\hline $\begin{array}{l}\text { Aragonite } \\
\text { (LeGeros and others, in press) }\end{array}$ & 1080 & $\begin{array}{l}842 \\
852\end{array}$ & $\begin{array}{l}1445 \\
1485\end{array}$ & $\begin{array}{l}700 \\
710\end{array}$ \\
\hline $\begin{array}{l}\text { Calcite } \\
\text { (LeGeros and others, in press) }\end{array}$ & & 872 & 1420 & 710 \\
\hline $\begin{array}{l}\text { Protein-free rat tibia, untreated } \\
\text { (Termine and Lundy, 1973) }\end{array}$ & & $\begin{array}{l}868 \\
877 *\end{array}$ & $\begin{array}{l}1417 \\
1441 * \\
1476\end{array}$ & \\
\hline $\begin{array}{l}\text { Protein-free rat tibia, air, } 24 \mathrm{hr} \\
\quad(\text { Termine and Lundy, 1973) }\end{array}$ & & $\begin{array}{l}870 \\
876\end{array}$ & $\begin{array}{l}1413 \\
1457 \\
1485 *\end{array}$ & \\
\hline
\end{tabular}

* Shoulder

occurred during fossilization and their possible effects on radiocarbon dating. The fossil bone specimens are from Folsom site, New Mexico; Murray Springs Clovis Level, Arizona; Blackwater Draw Clovis Level, New Mexico; Domebo Clovis Level, Oklahoma; and Boney Springs and Trolinger Bog, Missouri. They belong to B bison antiquus, Mammuthus columbi, Mammuthus, imperator, and Mammut americanum. The modern equivalents used in the study consist of buffalo (bison), cow, and elephant $(E \text { indictus })^{1}$. The elephant bones belong to two individuals; one died in 1967 and was left in open air while the other died in 1964 and was buried for 6 years prior to re-excavation.

\section{INFRARED SPECTROSCOPY}

Infrared (IR) absorption spectra from bone are usually composites of both protein and mineral absorption bands. The spectra of bone apatite are characterized by vibration bands produced by $\mathrm{H}_{2} \mathrm{O}, \mathrm{OH}, \mathrm{PO}_{4}$, and $\mathrm{CO}_{3}$ groups. The characteristic vibrational bands of the $\mathrm{CO}_{3}$ group in spectra of bone apatite are different from those observed in spectra of simple carbonate (table 1). The $\mathrm{CO}_{3}$ IR bands of fresh bone apatite (table 1) are more complex than those of dahllite (carbonate hydroxyapatite with less than 1 percent $\mathrm{F}^{-}$) and francolite (carbonate fluorapatite with more than 1 percent $\mathrm{F}^{-}$).

Generally $\mathrm{CO}_{3}$ exists in bone apatite at three different positions: (1) absorbed on the crystal surface, (2) at $\mathrm{OH}$-, and (3) at $\mathrm{PO}_{4}$-sites

${ }^{1}$ The elephant bones were obtained from Charles McNulty, University of Texas at Arlington. 
TABle 2

Chemical analysis of fresh, modern, and fossil bone apatite*

\begin{tabular}{lcccr}
\hline \multicolumn{1}{c}{ Sample description } & $\mathrm{Ca} \%$ & $\mathrm{PO}_{4} \%$ & $\mathrm{CO}_{3} \%$ & $\mathrm{~F} \%$ \\
\hline Fresh cow & 36.18 & 53.96 & - & .074 \\
Fresh buffalo & 36.06 & 52.93 & 5.75 & .035 \\
Modern elephant & 35.04 & 49.13 & - & .076 \\
Modern buried elephant & 34.94 & 48.93 & 6.50 & .055 \\
Folsom bison & 39.08 & 50.24 & 5.80 & 1.404 \\
Murray Springs mammoth & 37.46 & 49.28 & $\overline{6}$ & 1.467 \\
Blackwater Draw mammoth & 37.59 & 49.89 & 6.56 & 1.830 \\
Blackwater Draw mammoth III & 37.16 & 45.24 & $\overline{3.75}$ & 3.958 \\
Domebo mammoth & 36.67 & 48.44 & 9.78 & 1.659 \\
Boney Springs mastodon & 38.70 & 49.35 & $\overline{1.561}$ \\
Trolinger bog mastodon & 38.88 & 50.50 & 5.52 & 1.781 \\
\hline
\end{tabular}

* From Hassan (1976)

(LeGeros and others, 1967; LeGeros and others, 1969; Carlström, in press; and Elliott, in press). About one-third to two-thirds of the total carbonate occurs at the surface (Neuman \& Mulryan, 1967; Termine \& Eanes, 1972; Termine \& Lundy, 1973). The remainder is distributed between $\mathrm{PO}_{4^{-}}$and $\mathrm{OH}$-sites with the vast majority in $\mathrm{PO}_{4}$-sites.

The spectra of bone apatite were made with a Perkin-Elmer Model 621 Spectrophotometer, purged with dry air from pellets of $300 \mathrm{mg} \mathrm{kBr}$ and $2 \mathrm{mg}$ protein- and calcite-free samples. ${ }^{2}$ Some samples were treated with triammonium citrate and acetic acid to test the effect of these chemicals on carbonate removal. Machine adjustment was as follows: slit program $1 \mathrm{x}$, gain 4.5 , attenuator 11.00 , scan time $10 \times 4.5$, suppression 6 , and source $0.8 \mathrm{amp}$. The infrared splitting function SP, which is proportional to percentage crystallinity as determined by XRD, was calculated according to Termine and Posner (1966). The carbonate percentage was calculated from the ratio $A_{1} / A_{2}$, the ratio of the areas under the peaks of the carbonate ion asymmetric stretching frequency $\left(1550-1350 \mathrm{~cm}^{-1}\right)$ and the phosphate ion antisymmetric bending frequency $\left(800-450 \mathrm{~cm}^{-1}\right)$, and a standard whose $\mathrm{CO}_{3}$ content is known (Greenfield \& Eanes, 1972). The standard used in the present study is the modern buried elephant femur in which the $\mathrm{CO}_{3}$ content was previously determined by wet chemistry (Hassan, 1976). Some of the chemical analysis on the bones investigated appear in table 2.

The spectra (fig 1) and frequencies (table 3) for IR linear absorbance for bone indicate that during fossilization bone apatite had experienced some changes. The absorption at $1495 \mathrm{~cm}^{-1}$, attributed to surface and/ or amorphous carbonate, is absent or very weak in the fossil bone. The intensities of IR bands at 1542, 1445, and $880 \mathrm{~cm}^{-1}$, which stand for $\mathrm{CO}_{3}-\mathrm{OH}$ substitution, decrease while an increase occurs at the 1418 and $873 \mathrm{~cm}^{-1}$ bands, which stand for $\mathrm{CO}_{3}-\mathrm{PO}_{4}$ substitution, with fossilization. Despite these changes, the fossil bone apatites were still close to the dahllite-type of apatite with the exception of the bone of the Blackwater Draw Mammoth III, a francolite-type. It is noteworthy that this sample

${ }^{2}$ See Hassan (1976) for sample pretreatment. 


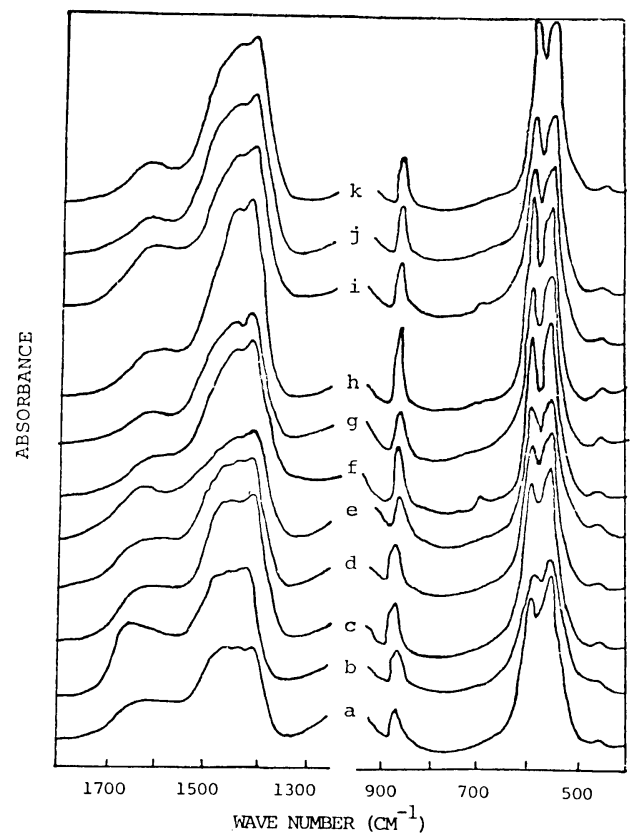

Fig. 1. Linear absorbance IR spectra from the bone of (A) fresh cow, (B) fresh buffalo, (C) modern elephant, (D) modern buried elephant, (E) Folsom bison, (F) Murray Springs mammoth, (G) Blackwater Draw mammoth, (H) Blackwater Draw mammoth III, and (K) Trolinger bog mastodon.

has an abnormally high $\mathrm{F}^{-}$concentration (3.96 percent) whereas the rest of the fossil bones have less than 1.9 percent and the fresh and modern bones contain less than 0.1 percent flouride (table 2). The fact that bone mineral dahllite may be converted into francolite because of fossilization, has been reported previously by Stevenson (1966).

The relative carbonate content of fossil bone apatite decreases sharply with triammonium citrate and acetic acid treatments (table 4). Prior to these chemical treatments, calcite was removed mechanically (Hassan, 1976). Any calcite remaining was below the detection limit of the IR, about 2 percent. The decrease in $\mathrm{CO}_{3}$ after the above treatments may well result from the weakening effect of the post-burial-substituted carbonate on bonds within the apatite structure. This is in agreement with the explanation of LeGeros and others (1967) for the observed increase in rates of dissolution and solubility of apatites with carbonate substitution.

\section{X-RAY STUDIES}

X-ray diffraction (XRD) broadening analysis has been extensively employed in the study of biological apatite (Carlström, 1955; Carlström and Glas, 1959; Posner and others, 1963, 1965; Harper and Posner, 1966; Termine and Posner, 1967; LeGeros and others, 1967; Posner, 1969; 
TABle 3

Frequency for IR absorption bands (in $\mathrm{cm}^{-1}$ ) for the carbonate in modern and fossil bone apatite

\begin{tabular}{|c|c|c|c|c|c|c|}
\hline \multirow[b]{2}{*}{ Sample description } & \multicolumn{2}{|c|}{$\begin{array}{c}\text { No } \\
\text { treatment }\end{array}$} & \multicolumn{2}{|c|}{$\begin{array}{c}\text { Triammonium } \\
\text { citrate }\end{array}$} & \multicolumn{2}{|c|}{$\begin{array}{l}\text { Acetic } \\
\text { acid }\end{array}$} \\
\hline & $\nu_{3}$ & $\nu_{3}$ & $\nu_{2}$ & $\nu_{3}$ & $\nu_{2}$ & $\nu_{3}$ \\
\hline$\overline{\text { Fresh cow }}$ & $\begin{array}{l}873 \\
880 *\end{array}$ & $\begin{array}{l}1417 \\
1445 \\
1470 \\
1495 * \\
1512 *\end{array}$ & - & $\begin{array}{l}- \\
- \\
-\end{array}$ & - & $\begin{array}{l}- \\
- \\
-\end{array}$ \\
\hline Fresh buffalo & $\begin{array}{l}873 \\
880^{*}\end{array}$ & $\begin{array}{l}1418 \\
1445 \\
1470 \\
1495 * \\
1512 *\end{array}$ & - & $\begin{array}{l}- \\
- \\
-\end{array}$ & - & $\begin{array}{l}- \\
- \\
-\end{array}$ \\
\hline Modern elephant & $\begin{array}{l}873 \\
880 *\end{array}$ & $\begin{array}{l}1418 \\
1445 \\
1470 \\
1500 *\end{array}$ & - & $\begin{array}{l}- \\
- \\
-\end{array}$ & - & $\frac{-}{-}$ \\
\hline Modern buried elephant & $\begin{array}{l}873 \\
880 *\end{array}$ & $\begin{array}{l}1418 \\
1445 \\
1470 \\
1495 * \\
1510 *\end{array}$ & $\begin{array}{l}873 \\
880 *\end{array}$ & $\begin{array}{l}1418 \\
1445 \\
1470 \\
1495 * \\
1510 *\end{array}$ & - & $\begin{array}{l}- \\
- \\
-\end{array}$ \\
\hline Folsom bison & $\begin{array}{l}868 \\
878 *\end{array}$ & $\begin{array}{l}1417 \\
1450 \\
1495 *\end{array}$ & - & - & - & - \\
\hline Murray Springs mammoth & $\begin{array}{l}873 \\
880 * *\end{array}$ & $\begin{array}{l}1423 \\
1453 \\
1495 * * * k\end{array}$ & $\begin{array}{l}873 \\
880 * * * *\end{array}$ & $\begin{array}{l}1423 \\
1453 \\
1495 *\end{array}$ & $\begin{array}{l}873 \\
880 * * *\end{array}$ & $\begin{array}{l}1423 \\
1453 \\
1495 *\end{array}$ \\
\hline Blackwater Draw mammoth & $\begin{array}{l}873 \\
880 * *\end{array}$ & $\begin{array}{l}1423 \\
1453 \\
1495 * * *\end{array}$ & $\begin{array}{l}873 \\
880 * *\end{array}$ & $\begin{array}{l}1423 \\
1453 \\
1495 *\end{array}$ & - & - \\
\hline Blackwater Draw mammoth III & 866 & $\begin{array}{l}1427 \\
1455\end{array}$ & 866 & $\begin{array}{l}1429 \\
1455\end{array}$ & 一 & - \\
\hline Domebo mammoth & $\begin{array}{l}873 \\
880 * * *\end{array}$ & $\begin{array}{l}1420 \\
1453 \\
1495 *\end{array}$ & $\begin{array}{l}873 \\
880 *\end{array}$ & $\begin{array}{l}1420 \\
1453 \\
1495 *\end{array}$ & $\begin{array}{l}873 \\
880 * * *\end{array}$ & $\begin{array}{l}1420 \\
1453 \\
1495 *\end{array}$ \\
\hline Boney Springs mastodon & $\begin{array}{l}873 \\
880 * * *\end{array}$ & $\begin{array}{l}1420 \\
1453 \\
1495 *\end{array}$ & - & - & - & - \\
\hline Trolinger bog mastodon & $\begin{array}{l}873 \\
880 * * *\end{array}$ & $\begin{array}{l}1422 \\
1453 \\
1495 *\end{array}$ & - & - & - & - \\
\hline
\end{tabular}

* Shoulder

** Very weak shoulder

*** Weak shoulder 
Lundy and Eanes, 1973; and Russell, Termine, and Arcoli, 1973). Crystallite size can be deduced from the broadened X-ray diffraction peaks using Scherrer's equation (Klug and Alexander, 1954). However, the figures for bone apatite crystallite dimensions and its crystallographic orientation are controversial (Carlström and Glas, 1959; Posner and others, 1963; and Höhling, Themann, and Vahl, 1966) which suggests that the validity of accurate crystallite size determination for bone apatite has not been settled. However, it is generally agreed that the crystals are extremely minute with the smallest dimension less than $50 \AA$ and the largest dimension much less than $1000 \AA$, paralleling the c-axis (Eanes, 1973).

Variability in unit cell dimensions of biological apatites resulting from chemical substitution and the mechanism of such substitution has also been a matter of controversy. Among the substitutions which may occur in the apatite structure is that of carbonate. Carbonate substitution was investigated by McConnell (1938, 1952a and b, 1959, 1962, 1965), Borneman-Starinkevich and Belov (1953), Trautz (1960), McClellan and Lehr (1969), Elliott (1965, in press), LeGeros (1965), LeGeros and others (1967), LeGeros and others (1968, in press), Simpson (1972), and Carlström (in press). Generally agreed is that in francolite, one carbonate and one fluorine substitute together for one phosphate in the apatite structure resulting in a nonlinear decrease in the a-axis. Experimental studies on bone powder and on synthetic apatite by Neuman and Mulryan (1949, 1967), Neuman and others (1949), Neuman (1950), Neuman and Weikel (1954), and Simpson (1967) indicate that surface exchange, ionic and isotopic, as well as recrystallization, may also occur in bone
apatites.

\section{TABLE 4}

Splitting functions (SP), the ratio $\mathrm{A}_{1} / \mathrm{A}_{2}$, and carbonate percentage calculated from $A_{1} / A_{2}$ using the wet chemical analysis for the modern buried elephant as a standard

\begin{tabular}{|c|c|c|c|c|c|c|c|c|c|}
\hline \multirow[b]{2}{*}{ Sample description } & \multicolumn{3}{|c|}{ No treatment } & \multicolumn{3}{|c|}{$\begin{array}{c}\text { Triammonium } \\
\text { citrate }\end{array}$} & \multicolumn{3}{|c|}{ Acetic acid } \\
\hline & SP & $\mathrm{A}_{1} / \mathrm{A}_{2}$ & $\mathrm{CO}_{3} \%$ & SP & $A_{1} / A_{2}$ & $\mathrm{CO}_{3} \%$ & SP & $\mathrm{A}_{1} / \mathrm{A}_{2}$ & $\mathrm{CO}_{3} \%$ \\
\hline Fresh cow & 0.042 & 0.880 & 4.3 & - & - & - & - & - & - \\
\hline $\begin{array}{l}\text { Fresh buffalo } \\
\text { Modern elephant }\end{array}$ & $\begin{array}{l}0.033 \\
0.036\end{array}$ & $\begin{array}{l}1.350 \\
1.314\end{array}$ & $\begin{array}{l}6.6 \\
6.4\end{array}$ & - & $\rightarrow$ & - & - & - & - \\
\hline $\begin{array}{l}\text { Modern elephant } \\
\text { Modern buried }\end{array}$ & & 1.314 & 6.4 & - & & & & 一 & 一 \\
\hline $\begin{array}{l}\text { clephant } \\
\text { Folsom bison }\end{array}$ & 0.023 & 1.327 & 6.5 & 0.023 & 1.296 & 6.3 & 一 & 一 & - \\
\hline $\begin{array}{l}\text { Folsom bison } \\
\text { Murray Springs }\end{array}$ & 0.047 & 1.345 & 6.6 & 一 & - & - & 一 & 一 & - \\
\hline $\begin{array}{l}\text { mammoth } \\
\text { Blackwater Draw }\end{array}$ & 0.086 & 1.568 & 7.7 & 0.057 & 1.064 & 5.2 & 0.076 & 0.708 & 3.5 \\
\hline & 0.059 & 1.327 & 6.5 & 0.047 & 1.067 & 5.2 & - & - & - \\
\hline $\begin{array}{l}\text { mammoth III } \\
\text { Domebo mammoth }\end{array}$ & 0.075 & 1.947 & 9.5 & 0.054 & 1.643 & 8.0 & - & & - \\
\hline $\begin{array}{l}\text { Domebo mammoth } \\
\text { Boney Springs }\end{array}$ & 0.057 & 1.515 & 7.4 & 0.038 & 1.048 & 5.1 & 0.049 & 0.870 & 4.3 \\
\hline $\begin{array}{l}\text { mastondon } \\
\text { Trolinger bog }\end{array}$ & 0.039 & 1.452 & 7.1 & 一 & - & - & 一 & - & 一 \\
\hline mastodon & 0.032 & 1.525 & 7.5 & - & - & - & 一 & - & -- \\
\hline
\end{tabular}


PLATE 1

A.

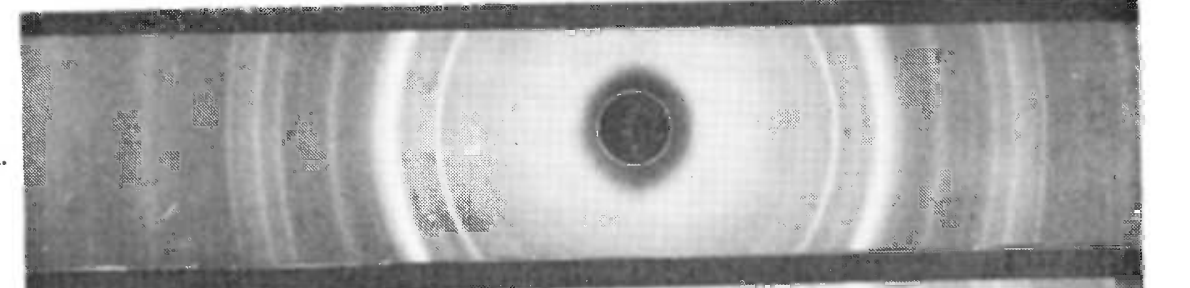

B.

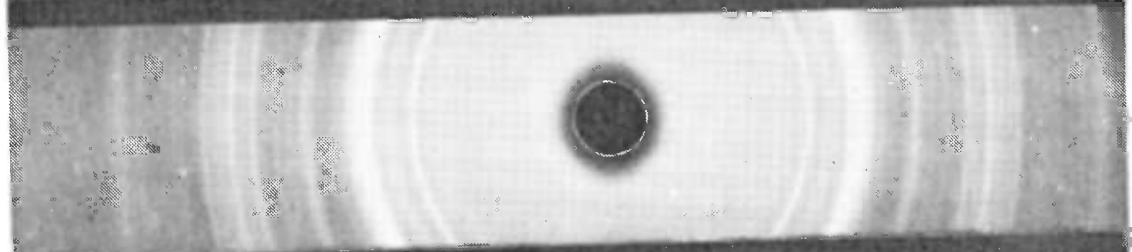

C.

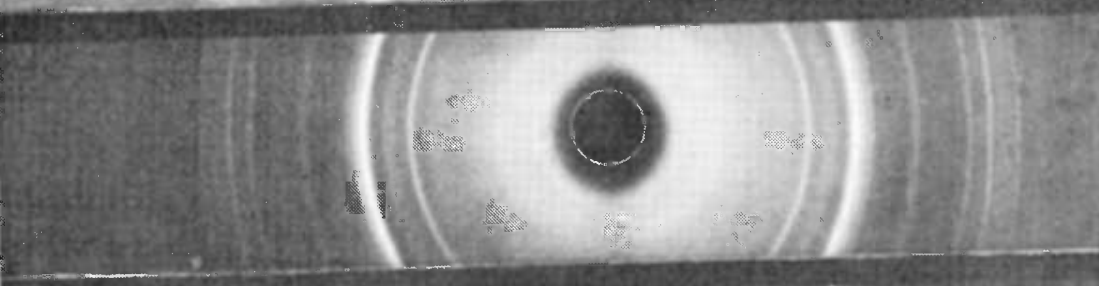

D.

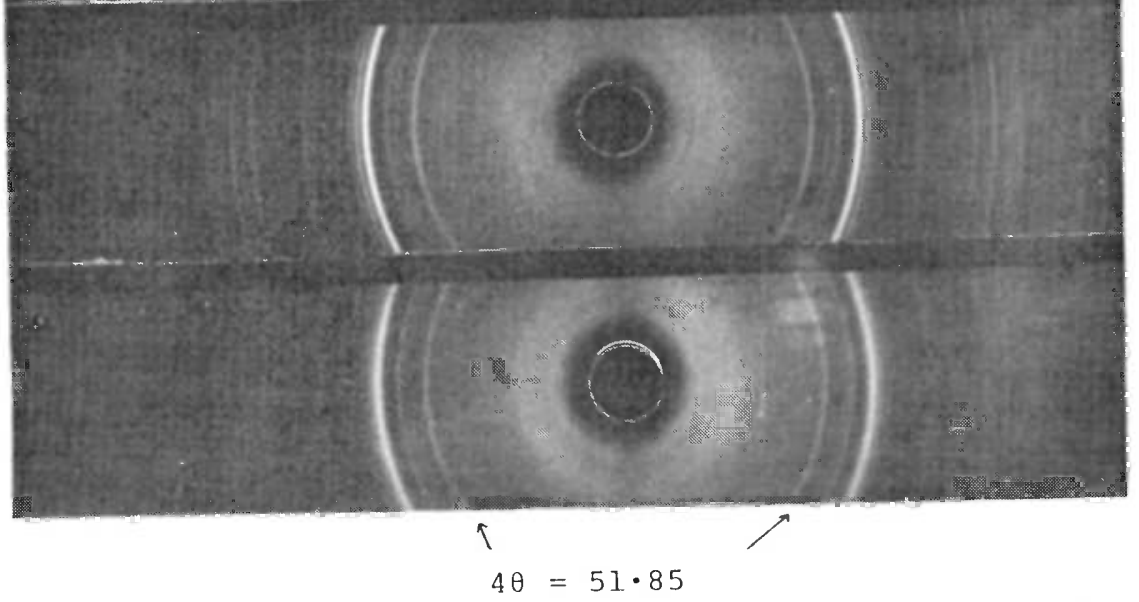

Exact positives of X-ray films of (A) fresh cow bone, (B) modern buried elephant bone, (C) Folsom bison bone, (D) Blackwater Draw Mammoth III bone, and (E) Domebo mammoth bone.

XRD peak broadening analyses were obtained from protein-free finely hand-ground samples ${ }^{3}$ adapting the method and experimental conditions of Russell, Termine, and Arcoli (1973). The apatite c-axis (002) and a-axis $(310)$ reflections were step-scanned between $23.60-27.60^{\circ} 2 \theta$ and $36.00-44.00^{\circ} 2 \theta$, respectively. Russell, Termine, and Arcoli (1973) ob-

${ }^{3}$ See Hassan (1976) for sample pre-treatment. 


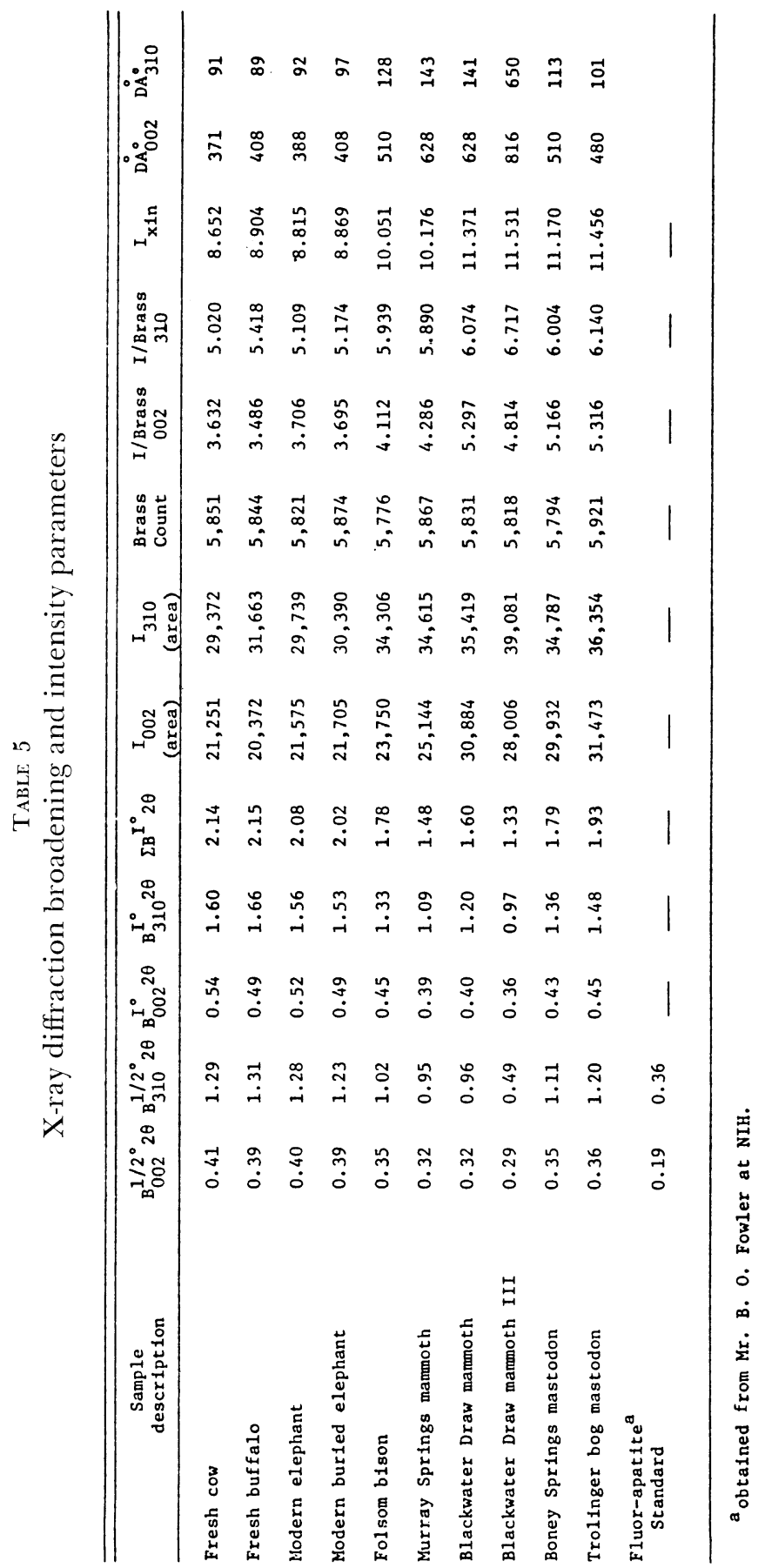


tained a precision in half-width (B 1/2) and integral breadth $\left(\mathrm{B}^{\mathrm{I}}=\right.$ peak area/peak height) values within \pm 1.5 percent. Debye-Scherrer, $114.6 \mathrm{~mm}$ diameter powder cameras were used for study of unit cell dimensions. With Ni-filtered $\mathrm{Cu}$ radiation $\left(\mathrm{CuK}_{2}=1.542 \AA\right)$, XRD patterns were recorded at $35 \mathrm{kv}$ and $20 \mathrm{ma}$. The exposure time was $2 \mathrm{hrs}$. The 002 and $300 \mathrm{X}$-ray diffraction lines were used to calculate c $\AA$ and a $\AA$ dimensions, respectively.

The crystallite dimensions, $\mathrm{D} \AA_{002}$ and $\mathrm{D} \AA_{310}$, of modern bone apatite obtained in the present study (table 5) have their small dimension parallel to the a-axis, in agreement with Carlström and Glas (1959). The crystallite size of bone apatite and/or the percent crystallinity increases with fossilization. The XRD lines (pl. 1) are sharper in fossil than modern bones which most probably results from crystallite enlargement. The calculated unit cell dimensions (table 6), even though not very accurate, show a distinction between modern and fossil bone apatite. The slight decrease in the a-axis with fossilization is consistent with the observed increase in fluorine and carbonate content detected with fossilization (tables 2 and 4 ).

\section{CONCLUSIONS AND PROBLEMS}

Fossil bone apatite undergoes a number of post-mortem changes which distinguishes it from its biological predecessor. Among those changes critical for radiocarbon dating is carbonate substitution. The present study reveals a definite change in the mode and amount of carbonate contained within bone apatite upon fossilization which suggests post-mortem exchange with exogenous carbon. Whether the exchange is ionic and/or isotopic is still unclear. Chemical treatments with triammonium citrate and/or acetic acid remove some of the carbonate in the apatite structure. Carbon isotopic studies (Hassan, 1976) indicate that the carbonates thus removed are contaminants. Hydrochloric acid leaching of the finely ground samples (fractional hydrolysis technique) removes more of the contaminated carbonate which then may improve the radiocarbon dates (Hassan, 1976).

TABLe 6

Unit cell measurements

\begin{tabular}{lcccccr}
\hline \multicolumn{1}{c}{ Sample description } & $\theta_{002}$ & $\theta_{300}$ & $\mathrm{~d}_{002}$ & $\mathrm{~d}_{300}$ & $\mathrm{c} \AA$ & $\mathrm{a} \AA$ \\
\hline Fresh cow femur & 12.9500 & 16.5750 & 3.4371 & 2.7001 & 6.87 & 9.35 \\
Modern buried elephant femur & 13.0125 & 16.6000 & 3.4215 & 2.6961 & 6.84 & 9.34 \\
Folsom bison bone & 13.0000 & 16.6125 & 3.4241 & 2.6945 & 6.85 & 9.33 \\
Murray Springs mammoth bone & 13.0250 & 16.6250 & 3.4176 & 2.6922 & 6.84 & 9.33 \\
Blackwater Draw mammoth III bone & 12.9625 & 16.6500 & 3.4345 & 2.6882 & 6.87 & 9.31 \\
Domebo mammoth bone & 12.9625 & 16.6500 & 3.4345 & 2.6882 & 6.87 & 9.31 \\
Boney Springs mastodon bone & 13.0250 & 16.6750 & 3.4176 & 2.6843 & 6.84 & 9.30 \\
Trolinger bog mastodon bone & 12.9825 & 16.6250 & 3.4393 & 2.6922 & 6.86 & 9.33 \\
Francolite* & - & - & - & - & 6.881 & 9.356 \\
Dahllite* & - & - & - & - & 6.890 & 9.391 \\
Bone** & - & - & - & - & $6.88 \pm 0.01$ & $9.38 \pm 0.01$ \\
\hline
\end{tabular}

* Trautz, 1955

** Posner and others, 1963 
In order to evaluate the magnitude and mechanism of post-mortem exchange of carbon in bone apatite, simulated lab experiments are essential. Carbonate substitution in both very old and fresh bone powder using either active or dead carbon should be investigated. Data derived from such studies test the validity of the above mentioned fractional hydrolysis and demonstrate the limitations of its applicability to this problem.

\section{AGKNOWLEDGMENTS}

The present study was partially supported by a grant from the Institute for the Study of Earth and Man, Southern Methodist University to A A Hassan and NSF Grants GA-12772 and DES72-01582 A01 to G V Haynes.

\section{REFERENGES}

Berger, R, Horney, A G, and Libby, W F, 1964, Radiocarbon dating of bone and shell from their organic components: Science, v 144, p 999-1001.

Berger, R, Protsch, R, Reynolds, R, Rozaire, C, and Sackett, J R, 1971, New radiocarbon dates based on bone collagen in California Paleoindian: Berkeley, Univ California Archaeol Research Facility Contr, no. 12, p 43-49.

Borneman-Starinkevich, I E, and Belov, N V, 1953, Carbonate-apatites: Akad Nauk SSSR Doklady, v 90, p 89-92.

Carlström, D, 1955, X-ray crystallographic studies on apatites and calcified structures: Acta Radialosia Supp, v 121, p 1-59.

Mineralogical carbonates containing apatites, in Brown, W, and Young, $\mathbf{R}$, eds, Internat symposium on the structural properties of hydroxy apatite and related compounds, 1968: New York, Gordon \& Breach (in press).

Carlström, D, and Glas, J E, 1959, The size and shape of the apatite crystallites in bone as determined from line broadening measurements on oriented specimens: Biochem Biophys Act, v 35, p 46-53.

Eanes, E D, 1973, Eleven X-ray diffraction of vertebrate hard tissue, in Zipkins, I, ed, Biological mineralization: New York, John Wiley \& Sons, Inc, p 227-256.

Elliott, J C, 1965, The interpretation of the infrared absorption spectra of some carbonate-containing apatites, in Stack, M V, and Fernhead, R W, eds, Tooth enamel, its composition, properties and fundamental structure: Bristol, John Wright \& Sons, Ltd, p 220, 50-58.

Synthetic and biological carbonates containing apatite, in Brown, $\mathrm{W}$, and Young, R, eds, Internat symposium on the structural properties of hydroxy apatites and related compounds, 1968: New York, Gordon \& Breach (in press).

Greenfield, D J, and Eanes, E D, 1972, Formation chemistry of amorphous calcium phosphates prepared from carbonate containing solutions: Calcified Tissue Research, v 9, p 152-162.

Hassan, A A, 1976, Geochemical and mineralogical studies on bone material and their implications for radiocarbon dating: PhD dissert, Southern Methodist Univ (Univ microfilms, Ann Arbor, Michigan).

Harper, R A, and Posner, A S, 1966, Measurement of non-crystalline calcium phosphate in bone mineral: Soc Expt Biol Med Proc, v 122, p 137-142.

Haynes, C V, Jr, 1968, Radiocarbon analysis of inorganic carbon of fossil bones and enamel: Science, v 161, p 687-688.

Höhling, H J, Themann, H, and Vahl, J, 1966, Collagen and apatite in hard tissues and pathological formation from a crystal chemical point of view, in Fleisch, $\mathbf{H}$, Blackwood, H J J, and Owen, M, eds, Calcified tissues, European symposium on calcified tissues, 3rd, Davos, 1965, Proc: New York, Springer-Verlag, p 146-151.

Klug, H P, and Alexander, L E, 1954, X-ray diffraction procedures for polycrystalline and amorphous materials: New York, John Wiley \& Sons, Inc, p 491-537.

Krueger, H W, 1965, The preservation and dating of collagen in ancient bones: Internat conf on radiocarbon and tritium dating, 6th, Pullman, Washington, 1965, Proc (CONF-650652), p 332-337.

LeGeros, R Z, 1965, Effect of carbonate in the lattice parameters of apatite: Nature, v 206, p 403-404.

LeGeros, R Z, LeGeros, J P, Trautz, O R, and Klein, E, 1968, Crystallographic studies on the $\mathrm{CO}_{3}$ substitution in the apatite structure: Soc Chim France Bull, spec no., p 1712-1718. 
LeGeros, R Z, Massuyes, M, Trombe, J C, Bonel, G, and Montel, G, Infrared and X-ray properties of synthetic carbonate apatites, in Brown, $\mathrm{W}$ and Young, R, eds, Internat symposium on the structural properties of hydroxy apatite and related compounds, 1968: New York, Gordon \& Breach (in press).

LeGeros, R Z, Trautz, O R, Klein, E, and LeGeros, J P, 1969, Two types of carbonate substitution in the apatite structure: Experimentia, v 15, p 5-7.

LeGeros, R Z, Trautz, O R, LeGeros, J P, and Klein, E, 1967, Apatite crystallites: effects of carbonate on morphology: Science, v 155, p 1409-1411

Longin, R, 1971, New method of collagen extraction for radiocarbon dating: Nature, v 230, p 241-242.

Lundy, D R, and Eanes, E D, 1973, An X-ray line-broadening study of turkey leg tendon: Arch Oral Biol, v 18, p 813-826.

McClellan, G H, and Lehr, J R, 1969, Chemical investigation of apatites: Am Mincralogist, v 54, no. 9-10, p 1374-1391.

McConnell, D, 1938, A structural investigation of the isomorphism of the apatite group: Am Mineralogist, v 23, p 1-19.

1952a, The problem of the carbonate apatites. IV. Structural substitutions involving $\mathrm{CO}_{3}=$ and $\mathrm{OH}^{-}$: Soc francaise mineralogic et crystallographie Bull, $\mathrm{v} 75$, p $428-445$.

_ 1952b, The crystal chemistry of carbonate apatites and their relationship to the composition of calcified tissues: Jour Dent Research, v 31, p 53-63.

1959, The problem of carbonate apatites: Econ Geology, v 54, p 749-751.

1962, The crystal structure of bone: Clin Orthopaed, no. 23, p 253-268.

1965 , Crystal chemistry of hydroxyapatite. Its relation to bone mineral: Arch Oral Biol, v 10, p 421-431.

Neuman, W F, 1950, Bone as a problem in surface chemistry, in Reifenstein, E, Jr, ed, Metabolic inter-relations, trans, 2nd conf: New York, Josiah Macy, Jr, Foundation, p 37-72.

Neuman, W F, and Mulryan, B J, 1949, Studies on the surface chemistry of bone 1Recrystallization: U S Atomic Energy Comm, AECU-132, p 1-9.

1967, Synthetic hydroxyapatite crystals, III. The carbonate system: Calcified Tissues Research, v 1, p 94-104.

Neuman, W F, Neuman, M W, Main, E R, and Mulryan, B J, 1949, The deposition of uranium in bone: Jour Biol Chem, v 179, p 325-348.

Neuman, W F, and Weikel, J H, Jr, 1954, Recrystallization in bone mineral: New York Acad Sci Annals, v 60, p 685-695.

Posner, A S, 1969, Crystal chemistry of bone mineral: Physiological Rev, v 49, p 760-792.

Posner, A S, Eanes, E D, Harper, R A, and Zipkins, I, 1963, X-ray diffraction analysis of the effect of fluoride on human bone apatite: Arch Oral Biol, v 8, p 549-570.

Posner, A S, Harper, R A, and Muller, S A, 1965, Age changes in the crystal chemistry in bone apatite: New York Acad Sci Annals, v 131, p 737-742.

Russell, J E, Terminc, J D, and Avioli, L V, 1973, Abnormal bone mineral maturation in the chronic uremic state: Jour Clin Inv, v 52, p 2848-2852.

Sellstedt, H, Engstrand, L, and Gejvall, N-G, 1966, New application of radiocarbon dating to collagen residue in bones: Nature, v 212, p 572-574.

Simpson, D R, 1967, Effect of pH and solution concentration on the composition of carbonate apatite: Am Mineralogist, v 52, p 896-902.

1972, Problems of the composition and structure of the bone minerals: Clin Orthopaed, v 86, p 260-286.

Stevenson, J S, 1966, Fluorine content of microsaur teeth from the Carboniferous rocks of Joggins, Nova Scotia: Science, v 154, p 1548-1550.

Tamers, M A, and Pearson, F J, Jr, 1965, Validity of radiocarbon dates on bone: Nature, v 208, p 1053-1055.

Termine, J D, and Eanes, E D, 1972, Comparative chemistry of amorphous and apatitic calcium phosphate preparations: Calcified Tissue Research, v 10, p 171-197.

Termine, J D, and Lundy, D R, 1973, Hydroxide and carbonate in rat bone mineral and its synthetic analogues: Calcified Tissue Research, v 13, p 73-82.

Termine, J D, and Posner, A S, 1966, Infrared determination of the percentage of crystallinity in apatitic calcium phosphates: Nature, v 211, p 268-270.

1967, Amorphous/crystalline interrelationships in bone mineral: Calcified Tissue Research, v 1, p 8-23.

Trautz, O R, 1955, X-ray diffraction of biological and synthetic apatites: New York Acad Sci Annals, v 60, p 696-712.

1960, Crystallographic studies of calcium carbonate phosphate: New York Acad Sci Annals, v 85, p 145-160. 